\title{
Ketertiban vs Hak Asasi Manusia (Studi Penertiban Terhadap Perempuan Pekerja Seks)
}

\section{Arini Robbi Izzati}

\author{
Peneliti di Pusat Studi Hak Asasi Manusia (PUSHAM) \\ Universitas Islam Indonesia Yogyakarta \\ E-mail: izzatirobbi@gmail.com
}

\begin{abstract}
This paper examines the curbing of women sex workers in the perspective of human rights (HAM). Human rights are the dimensions of human life. HAM is defined as a set of rights attached to the nature and existence of human beings as creatures of God Almighty and is a grace of His who must be respected, upheld and protected by the state, law, government, and everyone. Principally, although everyone is born with different skin color, gender, language, culture and citizenship, he still has those rights. This is universal. In addition to being universal, those rights can not be revoked (inalienable). The use of human rights approaches in this paper is further sharpened by feminist legal theory. This is done in order to bring the issue of curbing on women sex workers deeply. The focus of this article's review is how to curb sex worker women in a human rights perspective?
\end{abstract}

Keywords: Sex Worker Women, Control, Human Rights, and Feminist Law Theory.

\begin{abstract}
Abstrak
Tulisan ini mengkaji mengenai penertiban terhadap perempuan pekerja seks dalam perspektif hak asasi manusia (HAM). HAM adalah dimensi kehidupan manusia. HAM diartikan sebagai seperangkat hak yang melekat pada hakikat dan keberadaan manusia sebagai makhluk Tuhan Yang Maha Esa dan merupakan anugrah-Nya yang wajib dihormati, dijunjung tinggi dan di lindungi oleh negara, hukum, pemerintah, dan setiap orang. Prinsipnya meskipun setiap orang terlahir dengan warna kulit, jenis kelamin,
\end{abstract}


bahasa, budaya dan kewarganegaraan yang berbeda-beda, ia tetap mempunyai hak-hak tersebut. Inilah sifat universal. Selain bersifat universal, hak-hak itu juga tidak dapat dicabut (inalienable). Penggunaan pendekatan hak asasi manusia dalam tulisan ini makin dipertajam dengan teori hukum feminis. Hal ini dilakukan agar dapat mengahadirkan persoalan penertiban terhadap perempuan pekerja seks secara dalam. Fokus kajian artikel ini adalah bagaimana penertiban terhadap perempuan pekerja seks dalam perspektif hak asasi manusia?

Kata Kunci: Perempuan Pekerja Seks, Penertiban, Hak Asasi Manusia.

\section{A. Pendahuluan}

\section{Latar Belakang}

Prostitusi begitu menyejarah, tak pernah lekang termakan zaman. Berbagai pandangan tentang prostitusi pun tak ada habisnya bergumul dalam perdebatan; dikutuk, dilarang, dikelola, diatur. Perdebatan tersebut sangat tergantung pada kontestasi politik, ekonomi, hukum, sosial budaya, hingga morlitas agama yang tidak mau kalah dalam pemaknaan soal prostitusi. Tubuh yang ditransaksikan tidak pernah menemui ujung pangkalnya, tetap ajeg bertransformasi mengikuti gerak zaman. Mulai dari gadis-gadis candi (temple maidens) yang memiliki kehormatan luhur karena mempersembahkan keperawanan dalam upacara masyarakat purba. Atau seperti hetearea ${ }^{1}$ dan $g e i s h a^{2}$ yang memiliki status terhormat karena keterampilan, kecerdasan dan keanggunannya. Dan yang

${ }^{1}$ Dikenal sebagai pelacur kelas atas di masa Yunani Kuno. Hetearea dituntut untutk berperangai cerdas, anggun dan terhormat. Sehingga tak heran apabila mereka dapat ambil bagian dalam percakapan dengan lakilaki berpendidikan.

2 Pada dasarnya merupakan seniman. Namun dalam perkembangannya, geisha dikonotasikan sebagai "perempuan penghibur" yang dapat memberikan layanan seksual. Geisha memiliki status lebih tinggi di bandingkan perempuan pekerja seks jalanan karena mereka memeiliki keterampilan terutama dalam hal kesenian. 
paling tidak menguntungkan ialah meretrice, ${ }^{3}$ pornoi $^{4}$ dan khumbhadasi ${ }^{5}$ pekerja seks jalanan yang dipaksa memakai pakaian khusus untuk menandai profesinya dan membedakannya dengan perempuan-perempuan terhormat. Kini berabad telah berlalu tetapi atribut bagi perempuanperempuan tersebut tetap sama. Kehadiran bisnis seks seolah menjadi keniscayaan sejarah, ia mampu beringsut dan menggurita menjadi industry seks yang tak pernah sepi dalam remang maupun terang benderang.

Dalam sejarah manusia, hubungan yang melibatkan dua jenis kelamin (laki-laki dan perempuan) selalu meninggalkan pesan bagaimana relasi antara laki-laki dan perempuan terbangun. Pun dalam dunia prostitusi. Dimana relasi yang ada hadir dari ruang-ruang dominasi kekuasaan oleh laki-laki sebagai subyek dan perempuan sebagai objek. Dalam praktik prostitusi dominasi atas tubuh perempuan tak lain dipengaruhi oleh kuatnya prinsip patriarkhi suatu masyarakat yang mana laki-laki sebagai dominan akan mengotrol seksualitas perempuan dan institusi sosial seperti keluarga, hubungan heteroseksual, dan prostitusi.

Keluarga sebagai unit patriarkal terkecil merupakan sarana efektif dalam mensosialisasikan perbedaan peran seksual yang menguatkan kekuasaan laki-laki. Peranan perempuan pun didikotomikan pada satu pihak kesucian dan lain pihak kenafsuan. Keluarga mengakomodasikan kesucian perempuan sedangkan prostitusi mengakomodasikan kenafsuan. Dengan pandangan kesucian, seksualitas perempuan tidak dipertimbangkan tetapi diagungkan. Sedangkan dalam prostitusi kegairahan seksualitas perempuan diinginkan tetapi dianggap menyimpang. Dikotomi semacam ini membagi perempuan dan

3 Pelacur yang hina dan dipaksa memakai wig, melata, dan menggelandang di pojok kota masyarakat Romawi kelas bawah.

${ }^{4}$ Pelacur paling rendah pada masa Yunani Kuno.

${ }^{5}$ Pelacur rendahan di zaman India Kuno. 
menjadikannya semata-mata objek untuk kepentingan lakilaki sehingga memperkuat dominasi laki-laki. ${ }^{6}$ Masyarakat yang mendukung pandangan ini maka akan membenarkan kontrol atas seksualitas perempuan dan menganggap wajar tiap-tiap ekspresi dari agresivitas atas nama kelaki-lakian. Dalam hal ini prostitusi akan diterima karena dianggap merupakan hak laki-laki, walaupun harus ditempuh dengan cara pembelian seks, penjualan seks, ataupun perampokan seks.

Sulitnya menghilangkan praktik prostitusi berkaitan erat dengan hubungan kuasa yang dihasilkan melalui serangkaian diskursus dan interaksi yang kompleks (baik yang pro maupun yang kontra). Dalam satu rangkaian kegiatan prostitusi paling tidak didalamnya melibatkan para germo/ mucikari, calo, dan pastinya laki-laki pembeli seks. Pada skala tertentu praktik tersebut melembaga dengan melibatkan berbagai aparatus pendukung (misalnya oknum aparat keamanan) untuk memastikan bisnis seks aman terkendali. Simbiosis mutualisme makin terasa ketika masyarakat disekitaran lokasi prostitusi ikut diuntungkan dengan berbagai peluang kerja di sektor informal, bukankah tiap "obyek wisata" membutuhkan penginapan (kamar), tenaga parkir, petugas kebersihan, warung makan, warung minum, penjual pulsa, laundry, apalagi kesemuanya mendatangkan uang. Tak berhenti sampai disini, keuntungan bisnis ini pun menjalar sampai ke desa khususnya desa penghasil perempuan pekerja seks. ${ }^{7}$ Tak heran saat penutupan Dolly di

6 Thanh-Dam Truong, Seks, Uang dan Kekuasaan, ctk. Pertama (Jakarta: LP3ES, 1992), hlm. 20-23

${ }^{7}$ Mudjiono, Sarkem; Reproduksi Sosial Pelacuran, ctk. Pertama (Yogyakarta: Gadjah Mada University Press, 2005). Dalam buku tersebut dibahas bagaimana Sarkem menjadi perantara dalam proses produksi masyarakat sekitar lokasi prostitusi tersebut. Perputaran uang dari bisnis prostitusi juga berpengaruh ke daerah lainnya, dimana tingkat pengiriman uang ke daerah asal perempuan pekerja seks semakin tinggi seiring dengan penghasilan yang besar, secara tidak langsung perempuan pekerja 
akhir tahun 2015 proses tersebut cukup mendapat perlawanan dari perempuan pekerja seks, mucikari, maupun warga sekitaran wilayah tersebut.

Sikap pemerintah dalam menangani persoalan prostitusi dapat dikatakan tidak ada kemajuan, bahkan sejak zaman kolonial. ${ }^{8}$ Paradigma yang digunakan dalam merespon prostitusi masih saja seputaran kesehatan dan ketertiban masyarakat, bukan pada kesadaran moral untuk menyelesaikan persoalan sampai pada akarnya. Sampai saat ini belum ada undang-undang di Indonesia yang melarang menjual jasa seks atau aktivitas lain yang sejenis. Hukum pidana hanya melarang mereka yang membantu dan menyediakan layanan seks secara ilegal sebagaimana yang tertera dalam pasal 296, 297, dan 505 KUHP (Kitab Undangundang Hukum Pidana). KUHP juga melarang penukaran anak laki-laki dan perempuan dibawah umur.

seks turut melancarkan roda perekonomian desa-desa yang teridentifikasi sebagai penghasil perempuan pekerja seks. Lihat juga buku Tjahjo Purnomo \& Ashadi Siregar, Dolly; Membedah Dunia Pelacuran Surabaya, Kasus Kompleks Pelacuran Dolly, ctk. Pertama (Jakarta: Grafiti Pers, 1983), hlm. 137-145

${ }^{8}$ Terence H. Hull et. al., Pelacuran di Indonesia: Sejarah dan Perkembangannya, ctk. Pertama (Jakarta: Pustaka Sinar Harapan, 1997). Dalam buku tersebut diterangkan bahwa periode penjajahan Belanda sekitar tahun 1650 didirikan "Panti Perbaikan Perempuan" (house of correction for women) dengan maksud untuk merehabilitasi perempuan yang bekerja sebagai pemuas kebutuhan seks orang-orang Eropa dan melindungi mereka dari kecaman masyarakat. Hal ini menunjukkan bahwa jauh sebelum aturan tersebut lahir, praktik prostitusi sudah dikenal dan mendapat perhatian yang serius dari pemerintahan kolonial Belanda. Komersialisasi seks mendapat pengakuan (atau dapat diartikan sebagai persetujuan) di tahun 1852 dengan serangkaian aturan yang bertujuan untuk menjaga ketertiban dan mengurangi penyebaran penyakit menular seksual. Tahun-tahun selanjutnya kebijakan soal prostitusi tetap sama, hanya saja sejak tahun 1872 tanggungjawab pengawasan rumah bordil dialihkan dari pemerintah pusat ke pemerintah daerah. Tahun 1913 Hukum Moral Masyarakat yang dikeluarkan Belanda mengakhiri peraturan-peraturan lokal terkait prostitusi, peraturan ini menyebutkan tidak dibenarkannya tindakan pemucikarian. 
Apabila mendasarkan pada KUHP, pada hakekatnya sulit untuk menemukan dasar bahwa prostitusi merupakan kegiatan yang terlarang. Karena larangan untuk memberikan pelayanan seks secara komersial tidak ada dalam hukum negara, maka peraturan yang terkait dengan prostitusi cenderung didasarkan pada peraturan-peraturan lokal yang dikeluarkan oleh pemerintah daerah. Komnas Perempuan menghimpun bahwa sampai bulan Agustus 2012 terdapat setidaknya 96 kebijakan mengkriminalkan perempuan lewat pengaturan tentang prostitusi dan/ atau pornografi. ${ }^{9}$ Sudah jatuh tertimpa tangga pula, nasib perempuan pekerja seks yang sampai detik ini menjadi kelompok terpinggirkan dalam masyarakat makin tergerus dengan adanya Perda larangan pelacuran ataupun aturan yang sejenisnya. Corak Perda larangan prostitusi yang tersebar dibeberapa daerah hampir semuanya memiliki kesamaan, yakni berlandaskan pada moralitas umum dan menjaga ketertiban. Perda dengan dimensi moralitas yang kuat, atau disebut dengan "the legislation of morality", memiliki persinggungan yang cukup unik dengan lingkungannya. Dunia moralitas sangat sensitif, subyektif, dan majemuk, apalagi dengan corak kebangsaan seperti Indonesia. Sangat tidak mudah untuk menemukan suatu platform, dimana semua orang bisa berdiri diatas landasan yang relativ sama. Saat dihadapkan pada persoalan tarik menarik moralitas, pasti akan muncul pertanyaan mendasar: moral yang mana dan moral siapa?. ${ }^{10}$

Dalam konteks larangan prostitusi, tantangan sekaligus pertanyaan yang mendasar dari cita-cita ketertiban umum ialah: apa tolak ukur dari capaian ketertiban umum? Apakah dengan hilangnya prostitusi? Kalau memang keberhasilannya ialah dengan ner prostitusi, maka pertanyaan selanjutnya: mekanisme apa yang digunakan? Hal tersebut patut

${ }^{9}$ Lembar Hasil Kerja Komnas Perempuan 2012.

${ }^{10}$ Satjipto Rahardjo, Hukum dalam Jagat Ketertiban, ctk. Pertama (Jakarta: UKI Press, 2006), hlm. 88 
dipertanyakan mengingat trend penanganan prostitusi tak pernah berubah dari waktu ke waktu, masih mengedepankan tindakan represif (dengan bahasa penertiban) ketimbang menyelesaikan persoalan tersebut dengan basis pengalaman dan kebutuhan perempuan. Menelisik ruh dari kebijakan larangan prostitusi pun menjadi titik tolak dalam melihat persoalan ini. Dalih untuk menciptakan masyarakat yang beradab merupakan dasar dalam merumuskan kebijakan larangan prostitusi, sangat mulia sehingga patut untuk dimaknai benar. Namun, keadaban apa yang ingin dicapai sebenarnya? Beradab bagi siapa? Pertanyaan ini harus terjawab terlebih dahulu sebelum beranjak pada kebijakan larangan prostitusi. Terutama untuk mengendapkan pikiran kita pada kenyataannya bahwa masyarakat sudah terstratifikasi dalam kelas-kelas secara tegas. Dalam kondisi masyarakat kelas akses terhadap sumber kesejahteraan dan keadilan pastilah berlapis, ada kesenjangan ekonomi yang luar biasa tinggi, terdapat kelompok masyarakat yang begitu kaya-raya dan berkuasa secara politik-ekonomi, ada golongan menengah, dan golongan miskin dengan beragam variannya. Konsekuensinya, penikmatan yang tidak sama atas sumber daya dalam bingkai pembangunan melahirkan gap antara borjuasi dan proletar. Saat katup antar kelas makin menguat yang kemudian melahirkan pola-pola dominasi dan monopoli, adakah jaminan bahwa cita-cita keadaban tersebut tetap dalam bingkai keadilan.

Razia merupakan salah satu bentuk penertiban yang paling sering dilakukan dalam merespon masalah prostitusi, baik itu yang ada dijalanan maupun yang berada dilokasi pemukiman atau rumah yang disinyalir terdapat praktik tansaksi seks. Dengan melibatkan beberapa instansi terkait dalam proses tersebut (Satpol PP atau saat razia gabungan melibat Polisi dan Koramil) praktik prostitusi ditekan, lebihlebih dapat hilang sama sekali. Dalam proses tersebut perempuan pekerja seks seringkali menjadi sasaran tembak 
ketimbang mucikari ataupun pembeli seks. Bahkan yang bukan pekerja seks bisa juga jadi sasaran, selama dia secara subyektif dapat ditafsirkan sebegai perempuan pekerja seks. ${ }^{11}$ Pemandangan kucing-kucingan sampai kejar-kejaran antara petugas dengan perempuan pekerja seks menjadi hal yang lumrah dijumapi ketika penertiban perempuan pekerja seks. Mereka yang terjaring kemudian digiring menuju mobil patroli untuk selanjutnya dibawa ke kantor Satpol PP atau Kantor Polisi. Adakalanya proses tersebut terlihat dramatis namun sesekali juga terlihat datar, tanpa ekspresi, tak ada raut sedih ataupun takut, percakapan yang terjalin antara perempuan pekerja seks dan petugas pun terkesan akrab. Adegan semacam ini seringkali diparodikan dalam acaraacara hiburan/ komedi di televisi, proses tersebut juga mudah ditemui dalam sesi-sesi berita kriminal. Mempertontonkan dan memparodikan adegan penertiban perempuan pekerja seks dinegeri ini-atau mungkin dibelahan bumi lainnyamenjadi hal yang sangat wajar dan biasa saja. Seakan menegaskan bahwa proses tersebut benar adanya. Padahal proses tersebut tak ubahnya sedang mempertontonkan perburuan perempuan-menjaring perempuan-perempuan yang dapat dikonotasikan sebagai perempuan pekerja sekstentu saja dengan tafsir subyektif petugas terkait. Tidak

${ }^{11}$ Masih ingatkah dengan kasus Lilis dari Tanggerang, yang pada tahun 2006 menjadi korban salah tangkap Perda antiprostitusi.Ketika hendak pulang kerja Lilis diciduk petugas Trantib (Ketentraman dan Ketertiban). Lilis di tuduh sebagai pekerja seks karena memakai pakaian "seksi" ketika menunggu angkot. Lilis sempat dipenjara, dinyatakan bersalah dan "diadili" walaupun kemudian dibebaskan ketika keluarganya datang menjemput. Pasca dibebaskan Lilis stres dan kuguguran. Lilis berusaha menuntut Pemda Tangerang karena telah keliru dalam melakukan penahan dan pemvonisan dirinya, namun gagal. Kehidupan Lilis berangsur sura, ia kehilangan pekerjaan dan harus berpindah-pindah rumah lantaran tetangga tidak sudi ada "pelacur" yang tinggal di daerah mereka. Sanksi sosial dan trauma yang berkepanjangan menimbulkan beban mental yang berat bagi Lilis. Lilis wafat tahun 2008 meninggalkan suami dan anak semata wayangnya, Robby. 
(baca:belum) ada yang mempertanyakan apakah proses ini fair.

Penertiban prostitusi acapkali dinilai sebagai tindakan wajar (baca:benar) dalam rangka menjaga ketertiban masyarakat. Pada dasarnya hal ini tidak lepas dari imaji masyarakat itu sendiri tentang cita-cita tertib sosial. Saat imaji tersebut bermuara pada sebuah konsesus dan terlembaga maka dibutuhkan pranata sebagai mekanisme kontrol sosial. Hukum dalam hal ini dituntut bersifat netral, obyektif, mandiri dan a-politis (Positivisme Hukum). Namun se-netral dan se-obyektif apa hukum dalam struktur masyarakat patriarki yang masih sangat kuat. Dalam perspektif hukum feminis, netralitas hukum atau obyektifitas hukum ialah bentuk dari marginalisasi perempuan dalam bangunan hukum dan alienasi perempuan dalam ruang-ruang keadilan. Hukum feminis melihat adanya keterkaitan yang kuat antara hukum dengan relasi kuasa yang tak setara antara perempuan dan laki-laki. Bagi para feminis, hukum yang diyakini netral dan obyektif oleh teori Positivisme Hukum tidak mungkin ada. Sebab disadari atau tidak berbagai prodak hukum tersebut dibuat dalam perspektif patrairki yang lebih banyak menguntungkan laki-laki ketimbang perempuan. Bahkan hukum-hukum yang "berwarna patriarki" cenderung menindas dan seksis.

Begitu pula dalam persoalan prostitusi. Implementasi atas kebijakan yang terkait dengan penghapusan prostitusi telah melahirkan pola-pola baru kekerasan, marginalisasi, dan ketidakpastian hukum terhadap perempuan. Padahal dalam kesehariannya, kompleksitas kehidupan perempuan pekerja seks tak jarang mendekatkan mereka pada resiko-resiko yang sarat akan kekerasan. Hasil penelitian yang dilakukan P3SY (Perkumpulan Perempuan Pekerja Seks Yogyakarta) bekerja 
sama dengan PKBI DIY di tahun $2011^{12}$, menunjukkan menunjukan bahwa $61,3 \%$ perempuan pekerja seks di Sosrowijayan Kulon (Sarkem) pernah mengalami kekerasan. Kekerasan tersebut bentuknya bervarisi, mulai dari kekerasan fisik (dipukul, ditampar, dijambak, di tendang), kekerasan psikis (direndahkan, dibentak, dilecehkan, diancam), kekerasan seksual (dipaksa melakukan hubngan seks yang tidak dikehendaki), dan kekerasan ekonomi (di eksploitasi secara ekonomi, dibayar tidak sesuai kesepakatan). Pelakunya hampir sebagian besar ialah pelanggan, namun ada juga pelakunya ialah gandengan ${ }^{13}$ nya, dan ada juga pelaku kekerasan dari apparatus negara ketika perempuan pekerja seks mengalami penertiban.

Kasus-kasus kekerasan hanya sekelumit persoalan dan jarang sekali yang muncul ke permukaan. Ketiadaan perlindungan juga menjadikan perempuan pekerja seks beresiko menjadi korban eksploitasi secara ekonomi. Jasa keamanan lazim ditemui di titik lokasi prostitusi, tidak sedikit pula yang sampai melibatkan oknum aparat keamanan. Tentu saja dana yang disiapkan dalam mengamankan industi seks tidaklah sedikit. Dan siapakah yang menjadi penyuplai dana keamanan terbesar? Perempuan pekerja seks. Padahal dalam industry seks tidak ada pemain tunggal. Industri seks tidak hanya menyoal pembeli dan penjual seks yang ada kalanya diperantarai oleh germo. Industri seks selalu melibatkan pemilik-pemilik modal untuk memikat dan memanjakan

12 Hasil riset tidak diterbitkan. Dalam riset tersebut melibatkan kurang lebih 80 responden dari kampung Sosrowijayan Kulon, Pasar Kembang. Riset tersebut dilakukan untuk memetakan masalah kekerasan yang dialami perempuan pekerkja seks dan menjadi temuan menarik untuk kemudian mendorong terbentuk nya crisis center.

${ }^{13}$ Gandengan ialah pasangan hidup tidak resmi selama di Sarkem. Mereka hidup bersama dalam satu kamar, dan mereka juga menjalankan aktivitas kehidupan rumah tangga. Gandengan biasanya pendudk asli Sarkem atau dari luar daerah itu. 
pembeli agar terus bertransaksi. ${ }^{14}$ Dengan segala problematikanya perempuan pekerja seks menanggung beban paling berat dan penuh resiko, namun sayang miskin perlindungan. Persoalan semakin pelik lagi ketika perempuan pekerja seks harus di hadapkan dengan imaji atas bangunan tertib masyarakat yang menuntut mereka untuk tidak ada. Penertiban yang seringkali menyasar perempuan pekerjas seks seolah menutup mata atas peran pemain lain yang menenggak untung lebih banyak dalam industri seks. Begitu besarkah tanggungjawab perempuan pekerja seks dalam jagad ketertiban masyarakat sehingga pengalamanpengalaman mereka yang sarat kekerasan, diskriminasi dan eksploitasi tidak bernilai. Apakah perempuan pekerja seks tidak memiliki hak sebagaimana manusia lainnya, apakah mereka tidak memiliki hak asasi manusia? Dalam konteks penertiban yang menyasar pada industry seks-yang tentu saja bersinggungan dengan perempuan pekerja seks. Prinsip hak asasi manusia semestinya menjadi bagian dari nalar kebijakan dan nalar apparatus dalam merespon persoalan prostitusi. Kajian berikut ini akan mendalami hal tersebut.

\section{Rumusan Masalah}

Bagaimanakah penertiban terhadap perempuan pekerja seks dalam perspektif hak asasi manusia (HAM)?

${ }^{14}$ Namun pelibatan pemodal, pun dengan nilai dan untung yang besar, tidak selamanya akan menguntungkan bagi perempuan pekerja seks. Di Sarkem misalnya, sejak tahun 2012 room-yakni sebuah ruang karaoke - sudah mulai bermunculan dan kini makin banyak. Pembeli seks datang ke Sarkem kini tidak lagi hanya mencari kepuasan seks saja, namun juga mencari kesenangan tambahan dengan tuntutan mencari perempuan pekerja seks yang: bersuara merdu, pandai bernyanyi dan goyang, mau diajak mabuk dan yang pasti penutupnya dengan seks berbayar. Hal ini membawa dampak buruk bagi perempuan pekerja seks. Sebelumnya mereka thetek saja tanpa perlu mebekali diri dengan kemampuan bernyanyi dan bergoyang, namun keberadaan room membuat perempuan pekerja seks yang hanya bisa seks service menurun pendapatannya. 


\section{B. Kajian Teoritik}

\section{Wajah Perempuan dalam Hak Asasi Manusia}

Dalam Deklarasi Universal Hak Asasi Manusia disebutkan bahwa, “...semua orang dilahirkan bebas dan dengan martabat yang setara”. Namun, pada kenyataannya kebebasan, martabat, dan kesetaraan masih saja terlanggar di berbagai lini kehidupan. Hal ini pulalah yang mendasari beberapa feminis. Bagi kalangan feminis instrumentintrumen hak asasi manusia internasional miskin pengalaman perempuan dan perspektif gender. Definisi tentang hak asasi manusia dan mekanisme pendukung pemenuhan dan penghormatan hak asasi manusia lebih mengacu pada pelanggaran yang dikonseptualisasikan oleh laki-laki. Tak heran apabila definisi-definisi dalam serangkaian hak-hak asasi manusia jauh dari "narasi" perempuan.

Ialah Charlotte Bunch, tokoh feminis yang pertama melakukan transformasi konsep hak asasi manusia serta diskursus bahwa hak perempuan adalah hak asasi manusia. Ia menekankan bahwa hak-hak perempuan telah dilanggar dengan berbagai cara. Dalam kondisi politik tertentu, baik perempuan maupun laki-laki mengalami kekerasan. Akan tetapi, karena actor politik didominasi oleh laki-laki, masalah yang dialami perempuan menjadi "tidak kelihatan", invisible. Itulah sebabnya pengalaman kekerasan terhadap perempuan yang berbasis gender, yang dialaminya karena berjenis kelamin perempuan, seperti luput dari perhatian. ${ }^{15}$

Instrumen-instrumen hak asasi manusia yang dibangun diatas fundamen budaya patriarki lebih banyak mengungkapkan pengalaman-pengalaman ketidakadilan yang dialami oleh laki-laki dan seringkali tidak mengakomodari pengalaman-pengalaman yang khas perempuan. Akar persoalannya adalah egalitarianism formal yang mengabaikan

15 Saparinah Sadli, Berbeda tetapi Setara, ctk. Pertama (Jakarta: Kompas, 2010), hlm. 244 
aspek diferensiasi atau keperbedaan. Hal ini dirumuskan secara tepat oleh Ute Sacksofsky:

Persoalan utama diskriminasi terhadap perempuan dewasa ini terletak pada norma hukum yang dirumuskan secara netral berhubungan dengan gender.

Dalam kenyataannya netralitas tersebut berpijak pada budaya patriarki yang sekali lagi diikat, didukung dan diperkuat dengan norma hukum tersebut. ${ }^{16}$

Tidak berlebihan apabila beberapa pejuang hak-hak perempuan dari seluruh dunia mengkritik habis-habisan hukum dan system hak asasi manusia yang dinilai sangat maskulin dan patriarki. Hal tersebut dapat dilihat dari beberpa hal pertama, pendikotomian antara wilayah public dan privat; kedua, konsepsi pelanggaran hak asasi manusia sebagai pelanggaran yang dilakukan oleh Negara; ketiga, pendekatan "persamaan" (sameness) dan "perbedaan" (differences) yang dipakai oleh beberapa instrument pokok hak asasi manusia; keempat, pemilahan dan prioritas hak sipil dan politik ketimbang hak ekonomi, social, dan budaya. $^{17}$

Pendekatan hak asasi manusia yang konvensional lebih mengedepankan pengakuan jaminan terhadap hak-hak dalam lingkup public sementara wilayah domestic tidak dijangkau dengan dalih untuk melindungi privasi seseorang. Hal ini sangat merugikan perempuan yang berada dan selalu dekat dengan wilayah domestic. Dari pengalaman perempuan, justru beragam kekerasan dan diskriminasi terjadi di wilayah domestic secara serius dan massif. Namun situasi ini dianggap bukan pelanggaran hak asasi manusia dan hanya

16 Otto Gusti Madung, "Politik Diferensiasi Iris Marion Young, Keadilan Gender dan HAM", makalah disampaikan di Konferensi Perempuan I; Hukum dan Penghukuman tahun 2010 di UI Jakarta.

Rhona K.M Smith, et. al., Hukum Hak Asasi Manusia, ctk. Pertama (Yogyakarta: Pusat Studi Hak Asasi Manusia Universitas Islam Indonesia, 2008), hlm. 24-26 
digolongkan dalam tindakan criminal saja. Pemilahan antara wilayah public dan domestic berjalin dengan pandangan bahwa pelaku pelanggaran hak asasi manusia ialah Negara. Dalam banyak pengalaman perempuan, wilayah domestic tidak luput dari ajang eksploitasi, kekerasan, penyiksaan, dan diskriminasi terhadap perempaun dan anak. Namun hal ini tidak tersentuh dan sulit untuk diselesaikan melalui jalur hukum karena Negara — melalui aparatusnya — memilih untuk mendiamkan dengan dalih hal tersebut wilayah privat.

Pendekatan dalam prinsip non-diskriminasi yang mensyaratkan persamaan kedudukan setiap orang, sehingga setiap orang harus diperlakukan sama (sameness). Perlakuan khusus hanya diberikan pada perempuan yang menjalankan fungsi reproduksinya seperti melahirkan dan menyusui, dengan asusmsi perbedaan antara laki-laki dan perempuan hanya perbedaan biologis (difference). Pendekatan ini dipandang tidak melihat akar masalah perempuan dimana kekerasan dan diskriminasi muncul sebagai akibat dari timpangnya relasi kuasa antara perempuan dan laki-laki yang telah berjalan lama. Akibatnya perempuan selalu berada pada posisi tidak beruntung (disadvantages) di hampir seluruh aspek kehidupan yang tidak mudah dikembalikan pada posisi yang lebih baik jika tidak ada perlakuan dan perlindungan khusus. Perlakuan dan perlindungan khusus pun hanya menyasar pada perempuan yang berperan sebagai "ibu"menjalankan peran domestic saja. Sementara perempuan yang tidak menjadi "ibu" akan diperlakukan sama dengan laki-laki yang pada dasarnya lebih beruntung. Perlakuan yang sama antara laki-laki dan perempuan pada kondisi tertentu tentu saja akan menghambat akses perempuan pada keadilan.

Selain itu, pendekatan hak asasi manusia klasik lebih memprioritaskan sekaligus memilah-milah hak sipil dan politik dan meninggalkan hak ekonomi, social, dan budaya. Penekanan tentang hak hidup, misalnya, dimaknai sebagai hak untuk bebas dari hukuman mati. Tidak untuk mengatakan 
bahwa hak ini tidak penting, namun pemilihan wilayah tersebut telah berdampak pada pengkerdilan pelanggaran hak atas hidup dari aspek budaya dan social. Misalnya, tingginya AKI (Angka Kematian Ibu) saat melahirkan akibat layanan kesehatan yang tidak prima, minimnya perlindungan pada buruh migran yang mengakibatkan banyaknya kematian buruh migran perempuan di tangan majikan yg sewenangwenang, bukan dinilai sebagai pelanggaran hak atas hidup.

Persoalan-persoalan diatas menyiratkan bahwa persoalan perempuan masih "dipisahkan" dari hak asasi manusia. Hal ini berakar pada dominasi patriarki. Yang membuat perempuan memandang perlakuan non-egaliter yang seringkali dialaminya bukan sebagai sebuah perilaku ketidakadilan, tetapi sebagai sesuatu yang "normal atau kodrtati". Pada fase ini terjadi proses normaliasi kekerasan ataupun ketidakadilan. Jika pun perempuan berhasil mengartikulasikan pengalaman ketidakadilannya ke ruang public, hal ini belum tentu dapat diakomodasi oleh instruemn-instrumen hak asasi manusia. Alasannya, secara hukum hak asasi manusia hanya mengatur hubungan anatara kekeuasaan Negara dengan inividu.

Pemahaman ini berdampak fatal bagi pelanggaran hak asasi manusia yang khas untuk kaum perempuan. Pertama, perempuan sering tidak dipandang sebagai individu atau subyek hukum, tetapi sebagai elemen dalam sebuah kesatuan social dimana perempuan harus menjalankan peran dan funsi tertentu serta memenuhi harapan-harapan tertentu. Contoh, banyak janda di kabupaten Sikka dipaksa untuk menikahi adik dari mantan suami mereka kendati tanpa cinta. Alasannya, belsi atau emas kawin sudah di bayar lunas. Sang istri harus memenuhi kewajiban untuk emas kawin yang sudah diterima oleh keluarga besar perempuan. ${ }^{18}$

${ }^{18}$ Otto Gusti Madung, loc. cit. 
Kedua, karena perempuan dipandang sebagai satu elemen dari kesatuan kolektif yang lebih besar, dalam banyak kebudayaan, bidang kerja dan ranah social dimana perempuan berkiprah adalah keluarga atau ranah privat. Keridakadilan, kekersan dan diskriminasi seringkali terjadi di ranah ini sehingga lupur dari sorot pelanggaran hak asasi mnusia yang hanya berurusan dengan persoalan public. ${ }^{19}$

Faham hak asasi manusia yang dibangun dalam tatanan hukum liberal, keluarga tergolong dalam ranah privat yang harus dilindungi dari intervensi negara. Akibatnya, instrument hukum yang berpijak pada dikotomi liberal antara ranah privat dan public yang seakan-akan bekerja dengan kerangka hukum yang netral, tidak dapat memantau dan menangkap pelanggaran dan penistaan terhadap martabat manusia, otonomi dan integritas tubuh perempuan serat pengucilan dari ranah public. Pelanggaran ini berada pada ranah privat dan tidak boleh dikontrol oleh kekuasaan Negara.

Dalam hal ini kita melihat hubungan antara tatanan social yang sarat dengan nilai patriarki begitu diskriminatif terhadap perempuan serta instrument hak asasi manusia yang menerapkan konsep liberal tentang pemisahan ruang public dan privat. Pemisahan ini mempersulit dalam proses mengidentifikasi perlakuan yang tak sama terhadap perempuan sebagai pengalaman ketidakadilan. Karena tidak dapat diidentifikasi maka tidak dapat dilindungi dari instrument hak asasi mansuia.

Selain itu menurut Iris Marion Young, seoramg filsuf feminis kontemporer dari Amerika Serikat, ideologis netralitas hak asasi manusia tidak pernah ada. Dibalik netralitas hak asasi manusia terdapat konsep egalitarianism yang formal, gambaran manusia sebagai subyek otonom serta struktur social public yang patriarki. Struktur patriarki yang

\footnotetext{
${ }^{19}$ Ibid.
} 
kental mempersulit perempuan berkiprah diruang public serta mengungkapkan pengalaman-pengalaman ketidakadilan yang khas perempuan. Struktur patriarki menciptakan tahapantahapan pembentukan dan konstruksi hukum yang cenderung menindas perempuan. Jadi penindasan tidak hanya terjadi pada aplikasi praktis hukum. ${ }^{20}$

\section{Menyoal Persoalan Perempuan Melalui Teori Hukum Feminis}

Penertiban yang dilakukan terhadap perempuan pekerja seks tentu saja berdasar pada suatu peraturan, entah itu sifatnya nasional atau yang sifatnya lokalitas semacam Peraturan Daerah. Yang kesemuanya berdasarkan pada produk hukum. Hukum yang selama ini dipercaya tegak tak pandang bulu melindungi semua golongan dan menghadirkan rasa keadilan pada semua orang. Dalam paradigm positivism hukum, hukum dianggap mengandung kebenaran dan keadilan yang pasti. Hukum selalu ditempatkan sebagai panglima tertinggi dalam suatu Negara, dengan prinsip netralitas, obyektivitas, dan kepastian hukum menempati posisi "suci".

Prinsip netralitas dan obyektivitas benar adanya sebagai the law as ought to be. Namun untuk mewujudkannya dibutuhkan kondisi sine qua non, seperti struktur masyarakat yang tidak berlapis secara jelas, dimana setiap orang memiliki akses terhadap sumber kesejahteraan dan keadilan yang relative setara, dan birokrasi peradilannya relative bersih dari korupsi. Prinsip "equality before the law" dapat ditegakan dan memberikan keadilan secara pasti dan adil kepada hampir setiap warga Negara dalam kondisi diatas. Namun, dalam masyarakat yang sangat berlapis, implementasi atas prinsip "kesamaan dimuka hukum" menjadi diragukan untuk memberi keadilan yang sama.

\footnotetext{
${ }^{20}$ Ibid.
} 
Apalagi pada masyarakat yang didalamnya "menyimpan" berbagai persoalan ketidakadilan, dimana orang-orang yang berasal dari ras, kelas social, agama minoritas, dan jenis kelamin yang berbeda tidak mendapat akses perlakuan yang sama. Dalam kondisi seperti ini, maka prinsip "persamaan dimuka hukum" justru akan menimbulkan pertanyaanpertanyaan, bagaimanakah perlakuan yang diterima oleh pihak-pihak yang dianggap sebagai the other (liyan)?. ${ }^{21}$

Perempuan termasuk golongan yang kemudian mempertanyakan makna hukum dalam narasi pengalamannya. Apakah hukum telah menjamin setiap perempuan dalam memperoleh hak-hak dasarnya sebagai manusia? Apakah hukum telah menjamin bahwa perempuan akan aman dimanapun ia berada, dilindungi dari rupa-rupa kekerasaan terhadap dirinya, menjamin perempuan untuk bebas berekspresi dan mengontrol tubuhnya sendiri, menjamin bahwa keadilan juga milik perempuan?. Sayangnya, perjumpaan terhadap hukum yang membenarkan ketidaksetaraan dan membenarkan penindasan terhadap perempuan masih kuat bercokol.

Hukum secara konseptual adalah piranti formal yang dapat diandalkan, hukum diharapkan dapat memberikan keadilan bagi siapapun. Diskursus sosiologi hukum mensinyalir bahwa hukum adalah satu bentuk formal dari tafsir sosial atas realitas. Dalam konteks ini, hukum memiliki basis sosial-politik-kultural. Hukum adalah produk dialektika sosial-politik yang didasarkan pada cara pandang dan prinsip ideologis tertentu. Fineman lebih jauh menegaskan bahwa tidak ada pembagian yang tegas antara kekuasaan dan hukum. Menurutnya, hukum merepresentasi baik diskursus dan proses kekuasaan-dominasi; hukum dijumpai dalam

${ }^{21}$ Donny Danardono, Teori Hukum Feminis: Menolak Netralitas Hukum dalam Sulistyowati Irianto, ed., Perempuan dan Hukum: Menuju Hukum Berperspektif Kesetaraan dan Keadilan, ctk. Pertama (Jakarta: YOI, 2006), hlm. 29 
diskursus dan bahasa dalam dinamika kehidupan sehari-hari; hukum menjadi standar normatif bertingkah laku, dan merefleksikan pemahaman tentang apa-apa yang membentuk relasi kuasa dan social. Tidak hanya itu, di level penegakannya, hukum sangat rentan diintervensi oleh berbagai kepentingan dan kekuatan kultural, sosial, politis, ideologis dan kepentingan keagamaan. Dengan kata lain, kelahiran hukum dan penegakannya tidak pernah terjadi dalam setting yang vakum dan netral, terutama hukum yang bersinggungan dengan kepentingan ideologis. Diane Polan menegaskan bahwa "... hukum tidak beroperasi secara netral, ahistorikal, dan mandiri dari relasi kuasa yang ada di masyarakat. ... Lebih jauh, relasi kuasa tersebut harus dipahami dalam kaitannya dengan dimensi kelas sosial dan gender". 22

Teori hukum atau positivism hukum yang cenderung patriarkal dan maskulin mungkin tidak terlihat secara eksplisit. Namun beberapa kecenderungan menguatkan argument tersebut. Pertama, secara empiris dapat dikatakan bahwa hukum dan teori hukum adalah dominasi dari lakilaki. Dapat dikatakan laki-laki lah yang menulis hukum dan teori-teori hukum. Hampir dari keseluruhan pencetus teori hukum ialah laki-laki. Dengan demikian penulisan dan hasil pemikiran para ahli hukum yang hampir seluruhnya berjenis kelamin laki-laki itu langsung maupun tidk langsung akan mempengaruhi teori-teori yang dihasilkannya. Meskipun ideology maskulin tidak selalu muncul dari pemikiran lakilaki dan bisa saja berasal dari perempuan yang mengadopsi nilai-nilai maskulin tersebut, namun yang harus dipahami ialah; perkembangan teori-teori hukum terjadi manakal mayoritas yang memunculkan adalah laki-laki. Selain itu, teori-teori hukum muncul pada saat pemikiran tentang

${ }^{22}$ Noryamin, Nasib Perempuan Korban Kekerasan dalam Himpitan Hukum, Jurnal Kriminologi Indonesia Vol. 7 No.I Mei 2010, hlm. 67-107. 
kesetaraan gender belum mengemuka sehingga tidak dapat memberikan perimbangan pada ideology maskulin yang mendominasi. $^{23}$

Kedua, hukum beserta akibat-akibat yang ditimbulkan oleh teori hukum adalah refleksi dari nilai-nilai maskulin. Laki-laki telah menciptkan dunia hukum melalui imaji mereka dan mempertanyakannya dengan kebenaran yang menurut mereka absolut. Apa yang kemudian muncul dari nilai-nilai maskulin, itulah yang kemudian mendominsi dan mewarnai masyarakat, termasuk juga hukum dan apa yang dihasilkan oleh hukum. Catherine MacKinnon memberikan kritiknya terhadap hukum dengan dasar difference dan dominance; different theory maintains that law disadvantages women because it derives from male thought and experience. dominance theory asserts that male bias in law results from men subjection of women. ${ }^{24}$

Permasalah kemudian muncul, yakni ketika berkaitan dengan kelompok yang terpinggirkan dalam pembuatan keputusan dan teori-teori hukum. Permasalahan juga muncul pada adanya kesulitan yang melekat pada nilai-nilai yang ada pada system dan budaya yang diterapkan oleh kelompokkelompok tertentu. Bila nilai-nilai tersebut secara kultural melekat pada laki-laki dan kemudian melekat pula pada nilainilai hukum, maka tidak heran apabila hukum seakan-akan berbicara untuk laki-laki dalam kultur maskulin yang dominan. Hukum tidak akan berbicara atas nama perempuan ataupun kelompok terpinggirkan. Margaret Davies mengatakan bahwa bentuk ideology secara umum dari patriarkhi direproduksi dalam hukum itu sendiri, dimana

${ }^{23}$ Niken Savitri, HAM Perempuan - Kritik Teori Hukum Feminis terhadap KUHP. Cetakan Pertama. Bandung: PT. Refika Aditama, 2008, hlm. 81

${ }^{24}$ Ibid., hlm. 83 
substansi dan kategori hukum telah mengabaikan perhatian yang diperlukan oleh perempuan. ${ }^{25}$

Ketiga, dengan melihat kenyataan bahwa secara tradisional teori hukum adalah patriarkhi, maka hukum itu sendiri tidak netral dan kenyataan bahwa hukum dapat digunakan sebagai alat untuk menekan orang lain, tidak menjadi pertimbangan bagi pembuat hukum. Juga tidak menjadi pertimbangan bahwa banyak orang dalam banyak kasus dipengaruhi pesan tertentu dari hukum dan kultur yang ada, sehingga kekuatan dari ideology yang besar saja yang dapat memenangkan persengketaan dan pengaruh dari pesan tersebut. Hal ini menjadi relevan manakala seorang perempuan berhadapan dengan laki-laki dalam sengketa hukum dimana hukum akan berpihak pada kelompok dari mana ideology hukum berasal. Hal ini juga akan nampak ketika seorang penegak hukum (bisa laki-laki maupun perempuan) menerjemahkan pesan hukum tersebut kepada seoran perempuan korban, yakni dengan memaknainya dari pandang sudut laki-laki dan bukan pandang sudut perempuan. $^{26}$

Ketiga hal diatas merupakan ide dari teori hukum feminis yang tentu harus dibuktikan terjadi di dalam hukum. Tidak mudah mengatakan bahwa hukum yang ada patriarkis, karena secara kasat mata hukum begitu netral dan obyektif terhadap semua golongan. Namun akar persoalan sudah ada sejak dalam dalih-dalih pemikiran filosofis nya. Maka mustahil hasilnya akan berpihak pada semua golongan. Proposisi hubungan antara laki-laki dan perempuan secara filosofis sudah dirancang untuk tak setara, seperti pemikiran Aristoteles: "that the relation of male to female is naturally that of superior to the inferior the ruling to the ruled". ${ }^{27}$

\footnotetext{
${ }^{25}$ Ibid., hlm. 81-82

${ }^{26}$ Ibid.

${ }^{27}$ Ibid., hlm. 83
} 
Hukum sejak "dalam kandungan" memang sudah bias gender. Makin diperparah ketika pertarungan di proses legislasi banyak dipengaruhi pola pikir yang dominan. Sistem hukum merupakan ekspresi dari filsafat politik yang dominan dan sangat berpengaruh terhadap system hukum yang ada. Drowkin menyatakan: “... this philosophy is expressed in the values and traditions of the law and is worked out daily in the practice of developing law and deciding cases -it is not a purely academis philosophy. the political system is also made up of legal principles and these express the dominant political values of the system". ${ }^{28}$

Menurut Alan Hunt, hukum modern yang dimulai sejak masa Aufklarung diberi tempat yang istimewa sebagai penjaga batas antara rakyat dan Negara dan antara sesame individu yang dituangkan dalam legal rights. Hukum kemudian diterima sebagai fenomena tunggal, yakni hukum Negara yang mengekspresikan kedaulatan suatu Negara. Ia dibekali dengan penataan masyarakat secara rasional yang dilakukan dengan penggunaan prosedur netral dalam pengambilan keputusan di atas benturan antar kepentingan. Hukum sebagai fenomena tunggal inilah yang dalam penerapannya tidak dapat menangkap fenomena plural tentang kenyataan-kenyataan social yang hidup, diantaranya kebutuhan kelompok perempuan atas keadilan. Apalagi fenomena tunggal tersebut diwarnai oleh pengaruh dari ideology yang dominan dalam pembentukannya, yakni patriarkis. $^{29}$

Hukum yang berangkat dan dipengaruhi oleh nilai-nilai tertentu, dalam hal ini patriarkis, tidak lagi bisa mengatakan berpijak pada konsep netralitas dan obyektivitas hukum. Karean hukum dirumuskan dari ceruk-ceruk ideologis uang mendominasi. Hasilnya pasti adanya ketidakadilan bagi

\footnotetext{
${ }^{28}$ Ibid., hlm. 84

${ }^{29}$ Ibid., hlm. 85
} 
kelompok yang tidak mendominasi pola pikir pembuat hukum. Sehingga, kembali lagi, saat hukum diimplementasikan secara netral dan obyektiv, hasilnya adalah ketidakadilan bagi kelompok yang tidak terewakili secara dominan dalam perumusan tersebut, dalam hal ini adalah perempuan. Karenanya teori hukum feminis selain menyatakan adanya bias patriarkis didalam hukum, juga menolak adanya pelaksanaan hukum secara netral dan obyektif. Bagi teori hukum feminis konsep netralitas dan obyektivitas hukum hanyalah pengulangan ideologi patriarki pada pelaksaan hukum tersebut.

\section{Penertiban Terhadap Perempuan Pekerja Seks dalam Perspektif Hak Asasi Manusia}

Pada kenyataan penertiban terhadap perempuan pekerja seks tidak bisa tanpa dimensi kekerasan, hal ini semacam keniscayaan. Pengalaman perempuan pekerja seks ketika ditertibkan tak sepi dari pelanggaran hak asasi manusia. Kekerasan (mulai dari fisik, psikis, sampai verbal), diskriminasi, perlakuan sewenang-wenang, pelecehan, sampai dengan korban dari manipulasi proses hukum. Sempurna semua dialami perempuan pekerja seks. Tak sedikit pula rumusan hukum membuka peluang untuk membenarkan prasangka dan berujung pada pelanggaran hak asasi manusia. ${ }^{30}$

Dalam perspektif penegak hukum prostitusi hanya dipicu oleh perempuan dan penyelesaiannya dibebankan pada perempuan. Pada tubuh perempuan lah seluruh "dosa" prostitusi dibebankan. Hanya saja pembiaran atas pelanggaran tersebut lebih dipilih ketimbang menyelesaikan persoalan prostitusi dari akar permasalahannya. Melalui

30 Lihat http://icrp-online.org/2014/03/03/komnas-perempuandorong-judicial-review-perda-diskriminatif-gender/ diakses pada tanggal 12 April 2017 
penertiban Negara justru sedang melembagakan kategori abjek terhadap perempuan pekerja seks. ${ }^{31}$ Penciptaan kategori abjek berfungsi untuk menegakan perilaku yang "normal". Proses melekatkan abjek pada perilaku tertentu tidak hanya mensahkan penghukuman pada perilaku tersebut, tetapi juga menegakan batas-batas "normal" dan "abnormal" secara rigid dan terus menerus diawasi. Perempuan pekerja seks tidak dipandang sebagai individu utuh yang memiliki HAM, melainkan dilihat hanya sebagai perempuan-perempuan amoral yang kehidupannya bertentangan dengan niali-nilai kesusilaan. Pada kondisi ini kemudian stigma, diskriminasi dan kekerasan terhadap perempuan pekerja seks bekerja dan dibenarkan.

Dalam perspektif HAM penertiban terhadap perempuan pekerja seks tidak lebih dari mempertontonkan adegan demi adegan pelanggaran HAM. Padahal tidak sedikit UndangUndang yang menjamin bagi siapapun, termasuk perempuan pekerja seks, untuk bebas dari segala bentuk tindakan diskriminasi. Pasal 28 I ayat (2) UUD menjadi sumber hukum yang mengatur larangan diskriminasi terhadap siapapun dengan dasar apapun. Pasal ini menyebutkan bahwa setiap orang berhak bebas dari perlakuan yang bersifat diskriminatif atas dasar apa pun dan berhak mendapatkan perlindungan terhadap perlakuan yang bersifat diskriminatif. Pasal 3 Undang-undang Nomor 39 Tahun 1999 tentang HAM pun menjadi dasar perlindungan hukum bagi siapa pun untuk mendapatkan perlakuan dan perlindungan yang sama dimuka hukum dan tidak mendapatkan perlakuan diskriminasi. Pasal ini menyebutkan bahwa setiap orang dilahirkan bebas dengan harkat dan martabat manusia yang sama dan sederajat serta dikaruniai akal dan hati nurani untuk hidup bermasyarakat, berbangsa, dan bernegara dalam semangat persaudaraan

${ }^{31}$ Dari kata abject yang berarti hina atau rendah. Lihat Saskia E. Wieringa, et., al., Membongkar Seksualitas Perempuan yang Terbungkam, ctk. Pertama (Yogyakarta: LKiS, 2007), hlm. XV 
(Ayat 1). Setiap orang berhak atas pegakuan, jaminan, perlindungan dan perlakuan hukum yang adil serta mendapat kepastian hukum dan perlakuan yang sama di depan hukum (Ayat 2), Setiap orang berhak atas perlindungan hak asasi manusia dan kebebasan dasar manusia, tanpa diskriminasi (Ayat 3). Deklarasi Universal Hak Asasi Manusia Pasal 7 menjadi dasar hukum larangan perlakuan diskriminasi dengan alasan apa-pun kepada siapapun. Setiap perlakuan diskriminatif merupakan pelanggaran terhadap hak asasi manusia. Pasal ini menegaskan bahwa semua orang adalah sama dimuka hukum dan tanpa diskriminasi apapun berhak atas perlindungan hukum yang sama. Pengaturan terhadap hak untuk tidak mendapatkan perlakuan diskriminasi juga terdapat dalam International Covenant on Civil and Political Rights (ICCPR) yang telah di ratifikasi oleh pemerintah Indonesia melalui Undang-Undang Nomor 12 tahun 2005 menyebutkan bahwa semua orang adalah sama dihadapan hukum dan berhak untuk mendapatkan perlindungan hukum yang sama tanpa diskriminasi apapun (Pasal 26). International Covenant on Economic, Social and Cultural Rights (ICESCR) yang telah di ratifikasi pemerintah Indonesia melalui Undang-undang Nomor 11 tahun 2005 juga mengatur larangan Negara peserta untuk melakukan diskriminasi. Pasal 2 ayat (2) mengatur bahwa setiap negara anggota kovenan harus berusaha agar setiap warganya bisa menikmati hak-hak mereka tanpa adanya perlakuan dikriminasi. Convention on the Elimination of Discrimination against Women (CEDAW) yang telah di ratifikasi oleh pemerintah Indonesia melalui Undang-Undang Nomor 7 tahun 1984 dengan jelas mendefinisikan tindakan diskriminasi. Yakni pembedaan, pengucilan atau pemabatasan yang dibuat atas dasar jenis kelamin, yang mempunyai pengaruh atau tujuan untuk mengurangi atau menghapuskan pengakuan, penikmatan atau penggunaan hakhak asasi manusia dan kebebasan-kebebasan pokok di bidang 
politik, ekonomi, social, budaya, sipil atau apapun oleh perempuan, terlepas dari status perkawinan mereka, atas dasar persamaan antara perempuan dan laki-laki (pasal 1).

Rentetan jaminan perlindungan dari segala bentuk tindakan diskriminasi sepertinya-masih-dalam anganangan. Terutama bagi perempuan. Dalam iklim kehidupan yang ditopang dengan budaya patrairki relasi kuasa yang menghegemoni perempuan menjadi karakteristik yang menonjol. Bahkan beroprasi melampaui resistensi dan menjadi konsesus yang sangat alamiah dimana banyak perempuan yang tidak menyadarinya. Patriarki ${ }^{32}$ dapat dimaknai sebagai sebuah sistem struktur social dalam masyarakat yang hidup dan tumbuh dalam rentang historis yang cukup lama dan bertransformasi secara kontinyu. Dimana dalam hal ini laki-laki mempunyai posisi dominan dan dengan posisinya itu mereka melakukan eksploitasi terhadap perempuan yang mewujud dalam praktik sosial, ekonomi, politik, maupun budaya, baik dalam ruang privat maupun public. Dalam konteks penegakan hukum, bisa jadi pada saat penegakan hukum dijalankan bersamaan dengan itu

${ }^{32}$ Patriarki berasal dari bahasa Yunani patér, dengan bentuk genitif patris, dengan akar kata part yang bermakna "bapak" dan arché yang bermakna "tua" "awal", atau secara metaforis, "aturan". Patriarki merujuk pada harapan kultural bahwa seorang bapak mempunyai tanggung jawab utama terhadap kesejahteraan keluarganya (pada masa kebudayaan kuno, termasuk mengatur budak dalam keluarga). Patriarki kemudian digunakan dalam konteks yang lebih luas, yakni merujuk pada masyarakat yang mana kaum laki-laki memegang tanggung jawab untuk mesejahterakan komunitasnya secara menyeluruh sehingga mereka juga memegang tugas-tugas yang berkaitan dengan urusan publik. Sebagai sebuah sistem social patriarki menempatkan laki-laki sebagai sosok otoritas utama yang sentral dalam organisasi sosial. Ayah memiliki otoritas terhadap perempuan, anak-anak dan harta benda. Secara tersirat sistem ini melembagakan pemerintahan dan hak istimewa laki-laki dan menuntut subordinasi perempuan. Kebanyakan sistem patriarki juga adalah patrilineal. Patriarki adalah konsep yang digunakan dalam ilmuilmu sosial, terutama dalam antropologi dan studi referensi feministas. Lihat https://en.wikipedia.org/wiki/Patriarchy 
pula sistem tempat dimana laki-laki mendominasi, melakukan opresi dan melakukan eksploitasi atas perempuan.

Lebih lanjut, kita tidak bisa memandang hukum apa adanya (taken for granted) dalam bingkai netralitas, relasi social, politik, ekonomi, budaya, dan agama. Sebaliknya, dibutuhkan daya kritis untuk menyingkap tabir tentang kekuatan apa yang ikut bermain mempengaruhi eksistensi hukum. Karena baik secara normative maupun empiric hukum tidak bersifat netral, bebas dari segala bentuk kepentingan. Seorang eksponen feminis, MacKinon mengatakan bahwa: ${ }^{33}$

"Hukum mendefinisikan dan memperlakukan perempuan menurut cara dan logika lelaki memandang dan menyikapi perempuan baik secara sosial, kultural, politis maupun religius. Hukum digunakan sebagai instrumen ideologis untuk mendefinisikan dan mengontrol perilaku sosial dan masalah seksual perempuan".

Kebijakan mengenai penertiban dituangkan dalam kalimat-kalimat yang netral seolah hanya berujung pada pencapaian hakekat tertib. Namun corak masyarakat dimana hukum hidup, tumbuh, berkembang tidak dapat diabaikan sebagai veriabel yang mempengaruhi performa hukum. Penegakan hukum di Indonesia dibangun dalam struktur masyarakat patriarki sehingga proses tersebut belum memberikan pertimbangan yang berkeadilan bagi perempuan pada umumnya. Satjipto Raharjo ${ }^{34}$ memberikan catatan penting mengenai penegakan hukum sebagai proses untuk mewujudkan keinginan-keinginan hukum menjadi kenyataan, diantaranya ialah ide-ide keadilan. Selaras dengan hal

${ }^{33}$ Noryamin, Nasib Perempuan Korban Kekerasan dalam Himpitan Hukum, Jurnal Kriminologi Indonesia Vol. 7 No.I Mei 2010, hlm. 67 107.

${ }^{34}$ Niken Savitri, HAM Perempuan - Kritik Teori Hukum feminis terhadap KUHP, ctk. Pertama (Bandung: PT. Refika Aditama, 2008), hlm. 121-123 
tersebut, Boediono ${ }^{35}$ mengatakan bahwa tertib hukum bukanlah tertib hukum apabila tidak mengandung keadilan sehingga dia didukung oleh masyarakat sebagai subjek hukum umum. Persoalannya keadilan ialah masalah rasa, yang sangat relatif dan tiap orang memiliki kadar yang berbeda satu sama lainnya. Karena relative tersebut maka rasa keadilan tidak dapat diterapkan dan diberlakukan secara umum, dan setiap orang memiliki perasaaan subjektif yang membedakan adil dan tidak adil. Dibutuhkan adanya suatu media untuk mewujudkan pengertian tentang rasa keadilan yang diterima secara objektif oleh setiap orang. Disinilah hukum berperan, yakni rasa keadailan yang semula particular dan relative dijadikan satu rumusan yang objektif melalui rumusan hukum.

Kembali pada persoalan penertiban, dalam perspektiif hukum feminis proses tersebut sama sekali tidak menghadirkan rasa keadilan dan kepastian hukum bagi perempuan pekerja seks. Penertiban terhadap perempuan pekerja sesk, baik model konvensional maupun sample, dengan segudang persoalan justru melanggengkan praktikpraktik pelanggaran HAM. Penertiban terhadap perempuan pekerja seks tidak bisa dengan jumawa mengklaim bahwa kerja tersebut ialah penegakan hukum karena fakta dilapangan justru hukum sedang dipermainkan. Problem ini tidak akan selesai dan terus berkelanjutan apabila Negara tidak mengambil sikap tegas. Tinggal paradigma apa yang digunakan dalam merespon persoalan prostitusi. ${ }^{36}$ Tidak

${ }^{35}$ Ibid., hlm. 77.

36 Setidaknya terdapat empat paradigma yang berbeda dalam kaitannya dengan prostitusi. Pertama, prohibisonist yang berpendapat bahwa prostitusi ialah kejahatan dan harus dihukum baik penyedia, pembeli seks dan pekerja seks. Kedua, abolisionist yang menyatakan bahwa prostitusi adalah bentuk dari trafficking dan eksploitasi, dan segala bentuk industry seks harus dilarang. Dalam hal ini pekerja seks ialah dipandang sebagai korban, dan hal ini yang mendasari pandangan perempuan yang dilacurkan. Ketiga, regulasionist dengan pendapat 
mudah untuk dilakukan namun lebih tidak mudah untuk di diamkan. Karena berlarut-larut dalam budaya yang memaklumi keculasan lambat tapi pasti akan menjadi problem bangsa. Memapankan diri dalam budaya culas berarti kita sedang mengakui dan memberi ruang pada praktik-praktik diskriminatif terhadap mereka yang lain dan membenarkan nilai-nilai yang mendeskriditkan kelompok tertentu, dalam hal ini ialah perempua pekrja seks. Akankah beranjak atau memang tidak ada niat untuk beranjak pergi menjauh dan memilih untuk dekat melekat pada keadilan.

Negara sudah terlampau lama diam tidak bersikap dan memilih menutup mata-telinga atas realita praktik prostitus yang pola nya semakin canggih. Di era pemerintahan JokowiJK upaya serius negara dalam merespon persoalan prostitusi justru mengarah pada pelarangan praktik tersebut, menjadikannya ilegal. Melalui Kementirian Sosial wacana bebas prostitusi ditargetkan dapat terpenuhi di tahun 2019 makin menguatkan indikasi tersebut. ${ }^{37}$ Apabila tindakan tersebut yang diambil maka kebijakan tersebut menegaskan bahwa negara sama sekali tidak memahami akar persoalan dari prostitusi. "Merumahkan pekerja seks" memberi kesan bahwa apa yang dilakukan oleh perempuan pekerja seks ialah bagian dari jalanan, yang liar dan keras, bertolak belakang dengan konsepsi rumah sebagai tempat tinggal yang aman dan nyaman, tempat beristirahat melepas lelah setelah seharian bekerja. Dalam narasi perempua pekerja seks dijalanan atau dimana pun tidak menjadi soal, asalkan yang

bahwa prostitusi sebagai suatu kejahatan tidak dapat dielakan dari masyarakat, oleh karenanya dalam kondisi tertentu harus diatur. Pengaturan dalam hal ini ditujukan untuk menjaga ketertiban umum dan kesehatan umum. Keempat, decriminalization, yakni kerja seksual ialah pekerjaan oleh karenanya segala aturan tentang larangan pelacuran harus dihapuskan. Pandangan ini berfokus pada penghapusan pemaksaan dan kekerasan, serta pemenuhan hak-hak pekerja seks.

37 http://www.antaranews.com/berita/545548/mensos-pemerintahtargetkan-bebas-prostitusi-2019 diakses pada tanggal 12 April 2017. 
dirumah dalam keadaan kenyang dan kebutuhan dasar mereka terpenuhi. Program-program pengentasan yang selama ini jadi unggulan dari Kementrian Sosial tidak akan bisa mengantarkan perempuan pekerja seks sebagai individu baru karena polanya tidak pernah berubah dan hanya berorientasi pada program. Pemberian keterampilan memasak, menjahit, dan tata-boga pada perempuan pekerja seks mengulang kembali logika patriarki dimana peran perempuan ialah ranah domestic. Tidak ada pilihan lain selain keterampilan domestic. Padahal tidak ada factor tunggal yang mendasari seseorang menjadi perempuan pekerja seks, perempuan bukan satu entitas narasi. Apabila pengentasan yang dilakukan oleh Kementrian Sosial masih berdasar pada ketunggalan kebutuhan perempuan, maka selama itu pula program hanya sebatas program.

\section{Kesimpulan}

Penertiban terhadap perempuan pekerja seks tak dapat dipungkiri sarat dengan pelanggaran HAM. Namun hal ini cenderung di diamkan bahkan dibenarakan karena perempuan pekerja seks merupakan kategori abjek yang dinilai pantas untuk menerima segala bentuk kekerasan dan didiskriminasikan. Ketika rumusan hukum bekerja dalam struktur masyarakat patriarki maka penegakan hukum pun berimbas pada pembatasan perempuan terhadap ruang keadilan. Dalam perspektif hukum feminis penegakan hukum tidak akan memberi rasa keadilan terhadap perempuan selama tidak berangkat dari pengalaman perempuan.

Menjadikan prostitusi sebagai hal yang legal barangkali masih sangat jauh, atau barangkali tidak mungkin, di negeri ini. Namun setidaknya menghidupkan kembali resosialisasi bisa menjadi altermatif yang layak dicoba. Menghidupkan kembali resosialisasi menjadi salah satu saran dari penelitian ini-selain tentu saja aturan yang jelas dan humanis 
mengenai prostitusi. Melalui resosialisai setidaknya kompleksitas masalah perempuan pekerja seks dapat diantisipasi. Melalui resosialisasi kita bisa memantau keselamatan perempuan pekerja seks selama bekerja, memastikan bahwa perempuan pekerja seks memiliki hak yang sama dalam layanan kesehatan, memutus mata rantai eksploitasi terhadap perempuan pekerja seks, mencegah adanya pekerja seks anak dan pembeli seks anak, menutup kemungkinan adanya pekerja seks korban trafficking, dan menguatkan pekerja seks dalam pengelolaan finansial untuk mempersiapkan ketika akan purna tugas. Sangat disayangkan bahwa makin kesini pilihan yang diambil oleh pemerintah justru membubarkan resosialisasi, sebagaimana yang terjadi di Kalijodo. Kita masih bisa mengingat atau mencari jejakjejak keberhasilan dari Kramatunggak, sebuah konsep resosialisasi yang cukup baik dalam menangani segala problem yang terkait dengan perempuan pekerja seks.

Fakta di lapangan menunjukan bahwa ketika "area abuabu" dibuat tetap "abu-abu" maka celah untuk melakukan pelanggaran terbuka lebar. Celah inilah yang kemudian dimanfaatkan oleh pihak-pihak yang ingin mengambil banyak keuntungan dari bisnis prostitusi dengan menjadikan perempuan pekerja seks sapi perah. Menjadikan kerja seks sebagai tindakan criminal tidak akan menyelesaikan persoalan. Ketika kerja seks dikriminalkan maka praktik tersebut akan makin terselubung dan sulit untuk dijangkau. Hal ini akan membahayakan keselamatan dan kesehatan reproduksi perempuan pekerja seks itu sendiri. Kontrol pun makin sulit dilakukan karena peta titik dan mobilitas yang sulit diakses. Melalui resosialisasi diharapkan resiko-resiko kekerasan dan eksploitasi terhadap perempuan pekerja seks dapat diminimalisir. Selain itu yang terpenting melalui resosialisasi kita dapat mempersiapkan perempuan pekerja seks untuk purna tugas dengan kesadaran penuh dan pilihanpilihan yang memang telah siap untuk mereka jalani. 


\section{Daftar Pustaka}

\section{Buku}

Beauvoir, Simone De. Second Sex. Cetakan Pertama. Yogyakarta: Narasi, 2016.

Hull, Terence H. Et. al. Pelacuran di Indonesia: Sejarah dan Perkembangannya. Cetakan Pertama. Jakarta: Pustaka Sinar Harapan, 1997.

Irianto, Sulistyowati, coord ed. Perempuan dan Hukum: Menuju Hukum Berperspektif Kesetaraan dan Keadilan. Cetakan Pertama. Jakarta: YOI, 2006.

Koentjoro. On the Spot: Tutur dari Sang Pelacur. Cetakan Kedua. Yogyakarta: TINTA, 2004.

Moedjiono, Sarkem: Reproduksi Sosial Pelacuran, ctk. Pertama, Gajah Mada University Press, Yogyakarta, 2005.

Murray, Alison J. Pedagang Jalanan dan Pelacur di Jakarta. Cetakan Pertama. Jakarta: LP3ES, 1997.

Purnomo, Tjahjo dan Ashadi Siregar. Dolly; Membedah

Dunia Pelacuran Surabaya, Kasus Kompleks Pelacuran Dolly. Cetakan Pertama. Jakarta: Grafiti Pers, 1983.

Rahardjo, Satjipto. Hukum dalam Jagat Ketertiban. Cetakan Pertama. Jakarta: UKI Press, 2006.

Sadli, Saparinah. Berbeda tetapi Setara. Cetakan Pertama. Jakarta: Kompas, 2010.

Savitri, Niken. HAM Perempuan - Kritik Teori Hukum

Feminis terhadap KUHP. Cetakan Pertama. Bandung: PT. Refika Aditama, 2008.

Sedyaningsih, Endang R. Perempuan-Perempuan Kramat Tunggak. Cetakan Pertama. Jakarta, KPG, 2010. 
Soedjono, D. Pelacuran Ditinjau dari Segi Hukum dan Kenyataan dalam Masyarakat. Bandung: Karya Nusantara, 1977.

Smith, Rhona K.M. et. al. Hukum Hak Asasi Manusia. Cetakan Pertama. Yogyakarta: Pusat Studi Hak Asasi Manusia Universitas Islam Indonesia, 2008.

Truong, Thanh-Dam. Seks, Uang dan Kekuasaan. Cetakan Pertama. Jakarta: LP3ES, 1992.

Wieringa, Saskia E. et. al. Membongkar Seksualitas Perempuan yang Terbungkam. Cetakan Pertama. Yogyakarta: PT. LKiS, 2007.

\section{Jurnal}

Noryamin, Nasib Perempuan Korban Kekerasan dalam Himpitan Hukum, Jurnal Kriminologi Indonesia Vol. 7 No.I Mei 2010.

\section{Laporan}

Lembar Hasil Kerja Komnas Perempuan 2012.

\section{Makalah}

Madung, Otto Gusti. "Politik Diferensiasi Iris Marion Young,Keadilan Gender dan HAM", makalah disampaikan di Konferensi Perempuan I; Hukum dan Penghukuman di UI Jakarta, 2010.

\section{Website}

http://www.voaindonesia.com/a/komnas-banyak-perda diskriminatif-terhadap- perempuan/3348336.html https://en.wikipedia.org/wiki/Patriarchy http://www.antaranews.com/berita/545548/mensospemerintah-targetkan-bebas-prostitusi-2019 
